\title{
Mariya Olkhovych-Novosadyuk
}

Ivan Franko National University of Lviv

\section{COMMUNICATIVE LANGUAGE TEACHING: MANAGING THE LEARNING PROCESS}

\begin{abstract}
The article deals with the issues of the nature of communicative language teaching. Changing views on the nature of language and learning in relation to theories, objectives, syllabus, classroom activities and the roles of learners, teachers and material which led to the emergence of communicative language teaching are analyzed.

Methodology as a communicative process is investigated as well as communicative abilities of interpretation, expression and negotiation. The roles of the teacher and the learners within a communicative methodology are identified. Moreover, the concept of learnercenteredness is analyzed within the learning process domain.

A learner-centered curriculum has been compared with the traditional one pointing out similarities and differences between them. It is argued that communicative language teaching has had a major influence on language curriculum development. Therefore, curriculum decision-making in high-structure and low-structure contexts at the planning, implementation and evaluation stages is outlined in this paper. One of the main issues to be considered within curriculum content is needs analysis which provides a basis for setting goals and objectives. Hence, the salient characteristics of the three approaches to needs analysis are presented according to their educational rationale, the type of information collected, the method and the purposes of data collection.
\end{abstract}

Keywords: communicative language teaching, communicative methodology, learner-centeredness, communicative curriculum, needs analysis, curriculum content, evaluation, metacommunication.

\section{Introduction}

At a time when there is a recognized need in language teaching to give adequate attention to language use as well as language form, various 'notional-functional' or so- called 'communicative approaches' to language teaching are being advocated. The present paper is offered in an effort to define the nature of communicative language teaching. 
The communicative curriculum defines language learning as learning how to communicate as a member of a particular socio-cultural group. The social conventions governing language form and behavior within the group are, therefore, central to the process of language learning.

Communication in everyday life synthesizes ideational, interpersonal, and textual knowledge - and the affects which are part of such knowledge. But it is also related to and integrated with other forms of human behavior. The sharing and negotiating of potential meanings in a new language implies the use and refinement of perceptions, concepts and affects. Therefore, it makes sense for the teacher to see the overall purpose of language teaching as the development of the learner's communicative knowledge in the context of personal and social development.

\section{Communicative language teaching}

Communicative language teaching emerged from a number of disparate sources. During the 1970s and 1980s applied linguistics and language educators began to re-evaluate pedagogical practice in the light of changed views on the nature of language and learning, and the role of teachers and learners consequently. The contrast between what we have called "traditionalism", and communicative language teaching (CLT) proposed by David Nunan (1992), is shown in Table 1. The table presents contrasts in relation to theories of language and learning, and in relation to objectives, syllabus, classroom activities and the roles of learners, teachers and material.

Table 1

Changing views on the nature of language and learning

\begin{tabular}{|c|c|c|}
\hline Teaching & Traditionalism & Communicative language \\
\hline Theory of language & $\begin{array}{l}\text { Language is a system of rule- } \\
\text { governed structures } \\
\text { hierarchically arranged. }\end{array}$ & $\begin{array}{l}\text { Language is a system for the } \\
\text { expression of meaning: primary } \\
\text { function - interaction. }\end{array}$ \\
\hline Theory of learning & $\begin{array}{l}\text { Habit formation; skills are } \\
\text { learned more effectively if oral } \\
\text { precedes written; analogy not } \\
\text { analysis. }\end{array}$ & $\begin{array}{l}\text { Activities involving real } \\
\text { communication; carrying out } \\
\text { meaningful tasks and using } \\
\text { language that is meaningful to }\end{array}$ \\
\hline
\end{tabular}




\begin{tabular}{|c|c|c|}
\hline & & the learner promote learning. \\
\hline Objectives & $\begin{array}{l}\text { Control of the structures of } \\
\text { sound, form and order, mastery } \\
\text { over symbols of the language; } \\
\text { goal - native speaker mastery. }\end{array}$ & $\begin{array}{l}\text { Objectives will reflect the } \\
\text { needs of the learner; they will } \\
\text { include functional skills as well } \\
\text { as linguistic objectives. }\end{array}$ \\
\hline Syllabus & $\begin{array}{l}\text { Graded syllabus of phonology, } \\
\text { morphology, and syntax. } \\
\text { Contrastive analysis. }\end{array}$ & $\begin{array}{l}\text { Will include some or all of the } \\
\text { following: structures, functions, } \\
\text { notions, themes and tasks. } \\
\text { Ordering will be guided by } \\
\text { learner needs. }\end{array}$ \\
\hline Activities & $\begin{array}{l}\text { Dialogues and drills; repetition } \\
\text { and memori-zation; pattern } \\
\text { practice. }\end{array}$ & $\begin{array}{l}\text { Engage learners in } \\
\text { communication; involve } \\
\text { process such as information } \\
\text { sharing, negotiation of meaning } \\
\text { and interaction. }\end{array}$ \\
\hline Role of a learner & $\begin{array}{l}\text { Organisms that can be directed } \\
\text { by skilled training techniques } \\
\text { to produce correct responses. }\end{array}$ & $\begin{array}{lll}\text { Learner } & \text { as } & \text { negotiator, } \\
\text { interactor, giving as well } \\
\text { taking. }\end{array}$ \\
\hline Role of a teacher & $\begin{array}{l}\text { Central and active; teacher- } \\
\text { dominated method. Provides } \\
\text { model; controls direction and } \\
\text { pace. }\end{array}$ & $\begin{array}{l}\text { Facilitator of the } \\
\text { communication process, needs } \\
\text { analyst, counselor, process } \\
\text { manager. }\end{array}$ \\
\hline Role of materials & $\begin{array}{l}\text { Primarily teacher oriented. } \\
\text { Tapes and visuals; language lab } \\
\text { often used. }\end{array}$ & $\begin{array}{l}\text { Primary role of promoting } \\
\text { communicative language use; } \\
\text { task based, authentic materials. }\end{array}$ \\
\hline
\end{tabular}

Source: Nunan and Lamb 2001:31

The insight that communication was an integrated process rather than a set of discrete learning outcomes created a dilemma for language education. It meant that the destination (functioning in another language) and the route (attempting to learn the target 
language) moved much closer together, and, in some instances (for example, in role plays and simulations), became indistinguishable. In educational terms, a useful way of viewing this emerging dilemma in language education is in terms of high- and low-structure teaching. High-structure tasks are those in which teachers have all the power and control. Low-structure tasks are those in which power and control are devolved to the students. However, we do not equate high-structure with non-communicative and low-structure with communicative tasks.

\section{Methodology as a communicative Process}

Language learning within communicative curriculum is most appropriately seen as communicative interaction involving all the participants in the learning and including the various material resources on which the learning is exercised. Therefore, language learning may be seen as a process which grows out of the interaction between learners, teachers, texts and activities.

This communicative interaction is likely to engage the abilities within the learner's developing competence in an arena of cooperative negotiation, joint interpretation, and the sharing of expression. The communicative classroom can serve as a forum characterized by the activation of these abilities upon the learners' new and developing knowledge. This activation will depend on the provision of a range of different text-types in different media spoken, written, visual and audio-visual which the participants can make use of to develop their competence through a variety of activities and tasks.

Communicative abilities of interpretation, expression and negotiation are the essential or "primary" abilities within any target competence. Also, they continually interrelate with one another during communicative performance and are complex in nature. They will involve psychological processes, for example - and they may contain within them a range of secondary abilities such as "coding", "code substituting" and "styleshifting" (Bernstein, 1971, Hymes, 1971, Labov, 1972).

The use of these communicative abilities is manifested in communicative performance through a set of skills. Speaking, listening, reading and writing skills can be seen to serve and depend upon the underlying abilities of interpretation, expression and negotiation. The skills are the meeting point between underlying communicative competence and observable communicative performance; they are the means through which knowledge and 
abilities are translated into performance, and vice versa.

In order to allow for differences in personal interest and ease of access, or to permit the search for alternative perspectives on the content, learners should be offered the possibility of working with one or more of a range of media. Learners would be expected to act upon text-types in the appropriate medium: written texts would be read, spoken ones listened to, visual ones seen. Just as communication is governed by conventions, so we can see that different media represent and obey conventions specific to themselves.

Classroom procedures and activities can involve participants in both communicating and metacommunicating. By metacommunicating we imply the learner's activity in analyzing, monitoring and evaluating those knowledge systems implicit within the various text-types confronting during learning. Such metacommunication occurs within the communicative performance of the classroom as a sociolinguistic activity in its own right.

2.1. The roles of the teacher and the learners within a communicative
methodology

Within a communicative methodology the teacher has two main roles. The first role is to facilitate the communicative process between all the participants in the classroom, and between these participants and the various activities and texts. The second role is to act as an independent participant within the learning-teaching groups. These roles imply a set of secondary roles for the teacher: first, as an organizer of resources and as a resource himself. Second, as a guide within the classroom procedures and activities. This guidance role is ongoing and largely unpredictable, so the teacher needs to share it with other learners. Related to this, the teacher - and other learners - can offer and seek feedback at appropriate moments in learning-teaching activities. In guiding and monitoring the teacher needs to be a "seer of potential" with the aim of facilitating and shaping individual and group knowledge and exploitation of abilities during learning. In this way the teacher will be concentrating on the process competences of the learners.

A third role for the teacher is that of researcher and learner - with much to contribute in terms of appropriate knowledge and abilities, actual and observed experience of the nature of learning, and organizational capabilities.

As an interdependent participant in the process, the teacher needs to actively share the responsibility for learning and teaching with the learners. This sharing can provide the 
basis for joint negotiation which itself releases the teacher to become a coparticipant.

On the other hand, all learners of a language are confronted by the task of discovering how to learn the language. All learners - in their own ways - have to adopt the role of negotiation between themselves, their learning process, and the gradually revealed object of learning.

A communicative methodology is characterized by making this negotiative role - this learning how to learn - a public as well as a private undertaking. Learners also have an important monitoring role in addition to the degree of monitoring which they may apply subjectively to their own learning. In expression and negotiation, the learner adopts

the dual role of being, first, a potential teacher for other learners, and, second, an informant to the teacher concerning his own learning progress.

\subsection{Learner-centeredness}

The concept of learner-centeredness has been invoked with increasing frequency in recent years. The philosophy of learnercenteredness has strong links with experiential learning, humanistic psychology and task-based language teaching.

Table 2 shows how the continuum can apply to the learning process domain. Once again, we see that learner-centeredness is not an all-or-nothing process, but can be implemented in a series of gradual steps.

Table 2

\section{Learner-centeredness in the learning process domain}

\begin{tabular}{|c|c|l|}
\hline Level & Learner action & \multicolumn{1}{c|}{ Gloss } \\
\hline 1 & Awareness & $\begin{array}{l}\text { Learners identify strategy implications of } \\
\text { pedagogical tasks and identify their own preferred } \\
\text { learning styles / strategies }\end{array}$ \\
\hline 2 & Involvement & Learners make choices among a range of options. \\
\hline 3 & Intervention & Learners modify / adapt tasks. \\
\hline 4 & Creation & Learners create their own tasks \\
\hline 5 & Transcendence & Learners become teachers and researchers. \\
\hline
\end{tabular}

Source: Breen and Candlin 2001:170 
A learner-centered curriculum will contain similar elements to those contained in traditional curriculum development, that is, planning (including needs analysis, goal and objective setting), implementation (including methodology and material development) and evaluation. However, the main difference between learner-centered and traditional curriculum development is that, in the former, the curriculum is a collaborative effort between teachers and learners. Therefore, learners need to be systematically taught the skills needed to implement a learner-centered approach to pedagogy. In other words, language programs should have dual goals: language content goals and learning process goals.

\section{Language curriculum development}

As we can see from Table 3 (Source: Nunan and Lamb 2001), communicative language teaching has had a major influence on language curriculum development. First, curriculum development has become much more complex. Whereas twenty or thirty years ago, the point of departure for curriculum development tended to be restricted to the identification of the learner's current level of proficiency, with the development of communicative language teaching and the insight that curricula should reflect learner's communicative needs and learning preferences, much more information about and by learners came to be incorporated into the curriculum process. The other major modification occurred with the emergence of the communicative task as a central block within the curriculum. Instead of being designed to teach a particular lexical, phonological or morphological point, tasks were designed to reflect learners' communicative needs. Language focus exercises were developed as a second-order activity.

Table 3

Curriculum decision-making in high-structure and low-structure contexts

\begin{tabular}{|l|l|l|}
\hline \multirow{2}{*}{ Curricular elements } & \multicolumn{2}{|c|}{ M a n a g e m e n I s s u e s } \\
\cline { 2 - 3 } $\begin{array}{l}\text { At the planning stage } \\
\text { Course design }\end{array}$ & $\begin{array}{l}\text { What does the institution tell } \\
\text { me to teach? } \\
\text { What are the managerial } \\
\text { decisions entailed in the } \\
\text { teacher's manual? }\end{array}$ & $\begin{array}{l}\text { How do I design / adapt my } \\
\text { own content / goals / tasks? }\end{array}$ \\
\hline Needs analysis & $\begin{array}{l}\text { How can I identify the learning } \\
\text { preferences of my students? }\end{array}$ & $\begin{array}{l}\text { How can I involve my learners } \\
\text { in identifying and articulating }\end{array}$ \\
\hline
\end{tabular}




\begin{tabular}{|c|c|c|}
\hline & & their own needs? \\
\hline Collegial & $\begin{array}{l}\text { How can I cooperate with } \\
\text { colleagues in course planning? } \\
\text { How can I get the most out of } \\
\text { staff meetings? } \\
\text { How can sta } 63 \text { ings } \\
\text { contribute to ve } \\
\text { planning? }\end{array}$ & $\begin{array}{l}\text { What opportunities exist for } \\
\text { team teaching? }\end{array}$ \\
\hline Resources & $\begin{array}{l}\text { How do I manage use of set } \\
\text { text? }\end{array}$ & $\begin{array}{l}\text { How do I modify / adapt the } \\
\text { text? } \\
\text { How do I create my own } \\
\text { resources? } \\
\text { How do I design split } \\
\text { information tasks that will be } \\
\text { effective in my context? }\end{array}$ \\
\hline $\begin{array}{l}\text { At the implementation stage } \\
\text { Talk / interaction }\end{array}$ & $\begin{array}{l}\text { What are effective strategies } \\
\text { for direct instruction? } \\
\text { How do I give feedback on } \\
\text { high-structure tasks }\end{array}$ & $\begin{array}{l}\text { What questioning strategies } \\
\text { facilitate learner contributions } \\
\text { to low-structure tasks? } \\
\text { How do I give feedback in low- } \\
\text { structure tasks? } \\
\text { What types of teacher questions } \\
\text { maximize student output? }\end{array}$ \\
\hline Learner language & $\begin{array}{l}\text { How do I correct learner } \\
\text { errors? }\end{array}$ & $\begin{array}{l}\text { How can I provide language } \\
\text { models in small group role } \\
\text { plays in which the principal } \\
\text { focus is on the exchange of } \\
\text { meanings? }\end{array}$ \\
\hline Learner attitude & & $\begin{array}{l}\text { How do I deal with group } \\
\text { conflicts? } \\
\text { How do I deal with student } \\
\text { resistance to learner initiated } \\
\text { tasks? }\end{array}$ \\
\hline Group configuration & $\begin{array}{l}\text { How do I organize controlled } \\
\text { practice? } \\
\text { How do I manage teacher- } \\
\text { fronted instruction effectively? }\end{array}$ & $\begin{array}{l}\text { How do I set up small group } \\
\text { learning? } \\
\text { What strategies exist for setting } \\
\text { communicative tasks in which } \\
\text { students work independently? }\end{array}$ \\
\hline
\end{tabular}




\begin{tabular}{|l|l|l|}
\hline $\begin{array}{l}\text { At the evaluation stage } \\
\text { Learner assessment }\end{array}$ & $\begin{array}{l}\text { What techniques will help me } \\
\text { to assess the achievement of } \\
\text { my learners? }\end{array}$ & $\begin{array}{l}\text { How can I help my learners } \\
\text { develop effective techniques } \\
\text { for self-assessment? }\end{array}$ \\
\hline $\begin{array}{l}\text { Self-evaluation of the learning } \\
\text { process }\end{array}$ & & $\begin{array}{l}\text { How can learners be improved } \\
\text { in providing input to the } \\
\text { evaluation process? }\end{array}$ \\
\hline Formal evaluation & &
\end{tabular}

In summary, we can argue that curriculum development represents a delicate juggling act involving the incorporation of information about the learner, about the language, and about the learning process.

\subsection{Setting goals and objectives}

In the content domain, needs analysis provides a basis for setting goals and objectives. There are basically three different approaches to needs analysis. Brindley (1989) calls these approaches the language proficiency orientation, the psychological/humanistic orientation and the specific purpose orientation. The three approaches are differentiated according to their educational rationale, the type of information collected, the method of data collection and the purposes for which the data are collected. The salient characteristics of the three approaches are presented in Table 4 (Source: Brindley 1989: 67-69).

Table 4

Approaches to needs analysis

\begin{tabular}{|l|l|l|}
\hline \multicolumn{1}{|c|}{$\begin{array}{c}\text { Language proficiency } \\
\text { orientation }\end{array}$} & \multicolumn{1}{|c|}{$\begin{array}{c}\text { Psychological/humanistic } \\
\text { orientation }\end{array}$} & \multicolumn{1}{c|}{ Specific purpose orientation } \\
\hline $\begin{array}{l}\text { Educational rationale } \\
\text { Learners learn more effectively } \\
\text { if grouped according to } \\
\text { proficiency. }\end{array}$ & $\begin{array}{l}\text { Learners learn more effectively } \\
\text { if involved in the learning } \\
\text { process. }\end{array}$ & $\begin{array}{l}\text { Learners learn more effectively } \\
\text { if content is relevant to their } \\
\text { specific areas of need/interest. }\end{array}$ \\
\hline $\begin{array}{l}\text { Lype of information } \\
\text { difficulties }\end{array}$ & $\begin{array}{l}\text { Attitudes, motivation, learning } \\
\text { strategy preferences }\end{array}$ & $\begin{array}{l}\text { Information on native speaker } \\
\text { use of language in learners' } \\
\text { target communication situation }\end{array}$ \\
\hline
\end{tabular}




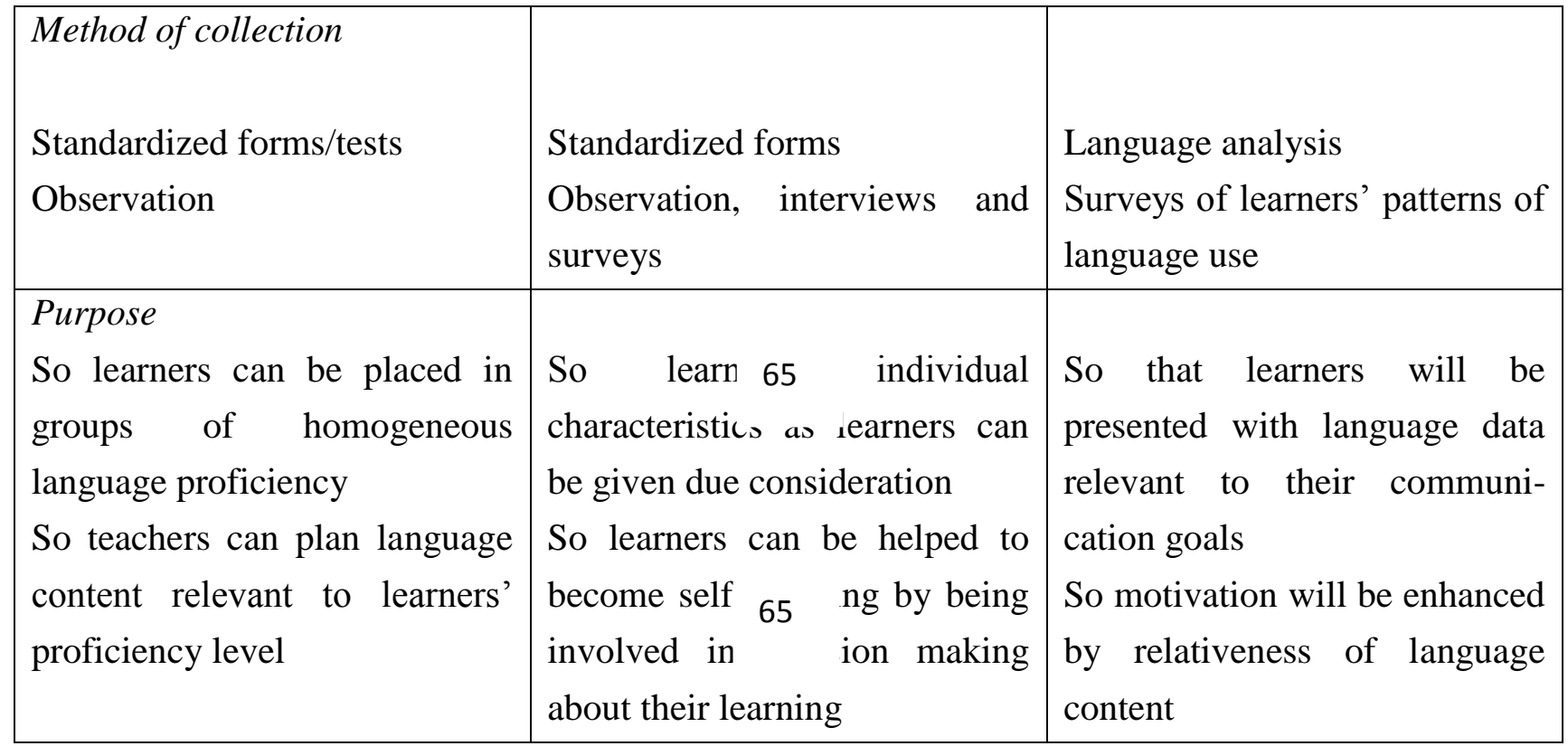

A major purpose for conducting needs analysis is to categorize and group learners. This grouping process facilitates the specification of content and learning procedures.

Goal and objective setting are important tasks in most educational contexts, because they provide a rationale for selecting and integrating pedagogical tasks, as well as providing a point of reference for the decision-making process.
An interesting set of specifications was developed in Australia by Scarino et al (1988). Called the Australian Language Levels (ALL) guidelines, these specifications were intended to be general enough to help material writers and teachers working in a range of second and foreign languages. The ALL guidelines take as their point of departure a number of broad goals that are refined into specific goals, as shown in Table 5 (Source: Scarino et al. 1988).

Table 5

Communication and learning-how-to-learn goals

\begin{tabular}{|l|l|}
\hline \multicolumn{1}{|c|}{ Broad goal } & \multicolumn{1}{c|}{ Specific goals } \\
\hline $\begin{array}{l}\text { Communication } \\
\text { By participating in activities organized around } \\
\text { use of the target language, learners will acquire } \\
\text { communication skills in the target language, in }\end{array}$ & $\begin{array}{l}\text { To be able to use the target language to: } \\
\text { - establish and maintain relationships and } \\
\text { discuss topics of interest (e.g., through exchange } \\
\text { of information, ideas, opinions, attitudes, }\end{array}$ \\
interpersonal relations, have direct access to & $\begin{array}{l}\text { feelings, experiences, plans); } \\
\text { - participate in social interaction related to }\end{array}$ \\
\hline
\end{tabular}




\begin{tabular}{|l|l|}
\hline $\begin{array}{l}\text { information and use their language skills for } \\
\text { study, vocational and leisure-based purposes }\end{array}$ & $\begin{array}{l}\text { solving a problem, making arrangements, } \\
\text { making decisions with others, and transacting to } \\
\text { obtain goods, services, and public information; } \\
\text { - obtain information by searching for specific } \\
\text { details in a spoken or written text and then } \\
\text { process and use information obtained; } \\
\text { - obtain information by listening to or reading a } \\
\text { spoken or written text as a whole, and then } \\
\text { process and use the information obtained; } \\
\text { - give information in spoken or written form } \\
\text { (e.g., give a talk, write an essay or a set of } \\
\text { instructions); } \\
\text { - listen to, read or view, and respond personally } \\
\text { to a stimulus (e.g., a story, play film, song, } \\
\text { poem, picture, play). }\end{array}$ \\
\hline $\begin{array}{l}\text { Learning-how-to-learn } \\
\text { Learners will be able to take a growing } \\
\text { responsibility for the management of their own } \\
\text { learning so that they learn how to learn, and how } \\
\text { to learn a language }\end{array}$ & $\begin{array}{l}\text { To develop: } \\
\text { - Cognitive processing skills (to enable them to } \\
\text { understand values, attitudes and feelings to } \\
\text { process information, and to think and respond } \\
\text { creatively); } \\
- \text { learning-how-to-learn skills; } \\
\text { - communication strategies (to enable them to } \\
\text { sustain communication in the target language). }\end{array}$ \\
\hline
\end{tabular}

Most curriculum documents based on a goal and objective approach contain a limited number of goals that provide a basis for the development of objectives. Formal performance objectives specify what learners should be able to do as a result of instruction. Formal objectives should contain a performance, conditions and standards.

\subsection{The content within communicative methodology}

The communicative curriculum will adopt criteria for the selection and organization of the content which will be subject to, and defined by, communicative learning and teaching. The content of any curriculum can be selected and organized on the basis of some adopted criteria, which will influence five basic aspects of content: its 
focus, its sequence, its subdivision, its continuity, and its direction (or routing).

The content within communicative methodology is likely to focus upon knowledge - both cognitive and affective which is personally significant to the learner. Such knowledge would be placed in an interpersonal context which can motivate personal and joint negotiation through the provision of authentic and problem-posing texts. If content is to be sensitive to the process of learning and to the interpersonal concerns of the group, it needs to reflect and support the integration of language with other forms of human experience and behavior.

Traditionally content has been subdivided into serialized categories of structures or 'functions'. Content would be subdivided in terms of activities and tasks to be undertaken, wherein both knowledge and abilities would be engaged in the learners' communication and metacommunication.

Within a communicative methodology, continuity can be identified within four areas. First, continuity can reside in the activities and the tasks within each activity; and from one activity to another. Second, continuity potentially resides within communicative acts during the learning and teaching. Third, continuity is provided through the ideational system. At the macro level the learner may have access to continuity of theme, while at the micro level - to conceptual or notional continuity. Fourth, continuity can reside within a skill repertoire or a cycle of skill-use during an activity. A communicative methodology would exploit each of these areas of continuity as clusters of potential continuities, rather than exploit any one alone. These kinds of continuity offer two important advantages. They can serve the full process competences of learners - knowledge systems and abilities - and they can allow differentiation.

\subsection{Evaluation of the curriculum process}

The communicative curriculum insists that evaluation is a highly significant part of communicative interaction itself. We judge "grammaticality", "appropriateness", "intelligibility", and "coherence" in communicative performance on the basis of shared, negotiated, and changing conventions.

A genuinely communicative use of evaluation will lead towards an emphasis on formative or ongoing evaluation, rather than summative or end-of-course evaluation which may be based on some prescribed criteria.

Therefore, the essential characteristics of evaluation within a communicative curriculum would be that such evaluation is itself incorporated within the communicative 
process of teaching and learning, that it serves the dual role of evaluating learner progress and the ongoing curriculum, and that it is likely to be formative in the achievement of dual role.

\section{Conclusions}

Communicative curricula need - through time and according to situation - to be open and subject to ongoing developments in theory, research, and practical classroom experience. Communicative curricula are essentially the means of capturing variability. Variability will exist in selected purposes, methods, and evaluation procedures, but variability must also be seen as inherent in human communication and in the ways it is variously achieved by different learners and teachers. The classroom - its socialpsychological reality, its procedures and activities - is potentially a communicative environment where the effort to pull together such variability is undertaken. The learningteaching process in the classroom is the meeting-point of all curriculum components and it is the place where their coherence is continually tested. The learning-teaching process in the classroom is also the catalyst for the development and refinement of those minimal requirements which will underlie future curricula.
A communicative curriculum with its emphasis on the learning and teaching of communication highlights a communicative process whereby the interrelating curriculum components are themselves open to negotiation and change.

Traditionally, learners have been expected to follow the direction implicit in some prescribed content. A communicative methodology would not exploit content as some pre-determined route with specific entry and exit points. In this case, content ceases to become some external control over learningteaching procedures. Choosing directions becomes a part of the curriculum itself, and involves negotiation between learners and teachers, and learners and text.

A communicative methodology will exploit the classroom as a resource with its own communicative potential. The classroom is only one resource in language teaching, but it is also the meeting-place of all other resources - learners, teachers, and texts. Each of these has sufficiently heterogeneous characteristics to make classroom-based negotiation a necessary undertaking. The authenticity of the classroom lies in its dual role of observatory and laboratory during a communicative learning-teaching process. 


\section{References}

Bernstein, B. 1971. Class, Codes and Control. London: Routledge and Kegan Paul.

Breen, M.P. and Candlin, C.N. 2001. The Essentials of a Communicative Curriculum in Language Teaching. Eds. D.R.Hall, A.Hewings. Innovation in English Language Teaching. A Reader. London and New York in association with Macquarie University and The Open University, pp.9-26.

Brindley, G., 1989. Assessing Achievement in a Learner-Centered Curriculum. Sydney: NCELTR.

Halliday, M. A. K., 1973. 'The functional basis of language' in Bernstein, B. (ed.) Class, Codes and Control, Volume 2: Applied Studies towards a Sociology of Language. London: Routledge and Kegan Paul.

Hymes, D., 1971. 'On communicative competence' in Pride, J. and Holms, J. (eds.) Sociolinguistics. Harmondsworth: Penguin Books, 1972.

Labov, W. 1972. Sociolinguistic Patterns. Philadelphia, PA: University of Pensylvania Press, pp.122-159.

Nunan, D. 1988. The Learner Centered Curriculum. Cambridge: Cambridge University Press.

Nunan, D. 1989. Designing Tasks for the Communicative Classroom. Cambridge: Cambridge University Press.

Nunan, D. 1992. Research Methods in Language Learning. New York: Cambridge University Press.

Nunan, D. and G. Brindley. 1986. The learner-centered curriculum in theory and practice. Paper presented at the Annual TESOL Convention, Anaheim, April 1986.

Nunan, D. and C. Lamb. 2001. Managing the learning process. Eds. D.R.Hall, A.Hewings. Innovation in English Language Teaching. A Reader. London and New York in association with Macquarie University and The Open University, pp.27-45.

Scarino, A., D. Vale, P. McKay and J. Clark. 1988. Australian Language Levels Guidelines. Canberra: Curriculum Development Centre. 